\title{
Obituary to Dr Yukio Ôhashi
}

\author{
Michio Yano* \\ Professor Emeritus of Kyoto Sangyo University
}

I intended to read this obituary at the Symposium on Calendars used in Asia, Oceania, Mexico, and Andes, 14-15 March, 2020 in Nanzan University, but the symposium was cancelled due to the new coronavirus problem. Dr. Yukio Ôhashi passed away sometime in October

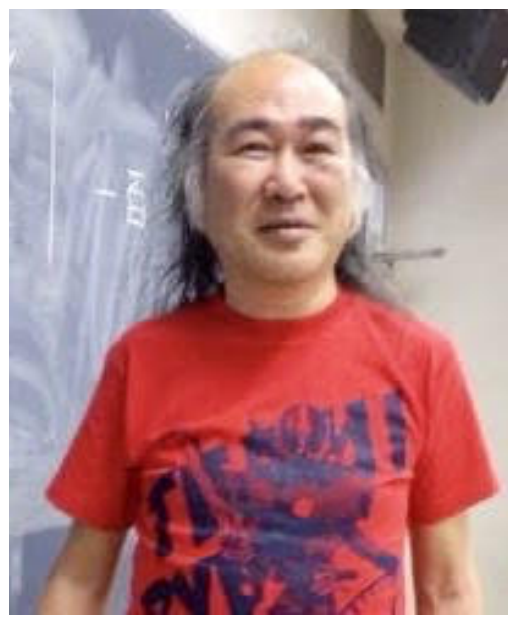

Yukio Ôhashi (1955-2019)

2019. 'Sometime' means that the exact date and time of his death is not known. He was living in his own house in Tokyo all alone after his mother died several years ago.

I could not believe when I got this sad news on November 10. It was only on March 12, 2019 that we participated in the Seventh Symposium on History of Astronomy held at the National Astronomical Observatory in Tokyo. After the symposium we joined a dinner party together. We discussed various topics. Ôhashi was very eloquent. He drank two or three bottles of wine even though he said that he was told by his doctor not to drink too much. I was worried about him.

Ôhashi was born on March 13, 1955 in Tokyo. He got M.A. from the department of Chinese studies in Saitama University in 1983. He was first interested in Chinese and

DOI: $10.16943 / \mathrm{ijhs} / 2020 / \mathrm{v55i1} / 152346$

${ }^{*}$ Email: yanom@cc.kyoto-su.ac.jp
Tibetan astronomy. The title of his M. A. thesis is 'Some problems of Hùhàn sìfēn lì' where he discussed one of the oldest official calendars in China. Thereafter he was enrolled in the doctorate course of Hitotsubashi University and studied modern astronomy. At the same time he got interested in the history of Indian astronomy and began learning Sanskrit and Hindi in the Eastern Institute (Toho Gakuin). From the same institute he was awarded scholarship to study in India. He was accepted by the University of Lucknow, India, and he studied under the guidance of Prof. K.S. Shukla from 1983 to 1987. Prof. Shukla was a great mentor and Ôhashi was one of his very few students. Eventually he got a Ph.D. in 1992. The title of the dissertation is A History of Astronomical Instruments in India. This dissertation was published in three installments in Indian Journal of History of Science (IJHS):

1. Development of Astronomical Observation in Vedic and Post-Vedic India, IJHS 28(3), 1993, 185-251.

2. Astronomical Instruments in Classical Siddhāntas, IJHS 29(2), 1994, 155-313.

3. Early History of the Astrolabe in India, IJHS 32(3), 1997, 199-295.

After he came back to Japan in 1988 he returned to the doctorate course of Hitotsubashi University and finished the course work in 1989. In spite of very high academic achievements he could not find any permanent research job and he worked as a part time lecturer of Chinese language, history of science, and history of astronomy, in several different universities. Whenever I was asked I wrote recommendation letters for him, but always in vain.

He applied to the assistantship of the Institute for Research in Humanities at Kyoto University, but he was not successful and he became rather pessimistic in finding a permanent job and gradually he turned to be aggressive to the established institutes and scholars and he was proud 
of calling himself 'amateur historian of astronomy'. It seems that he wanted to say that amateurs represented by him are more learned than professional scholars who have permanent job.

After his death Prof. Takao Hayashi prepared a list of Ôhashi's publications. ${ }^{1}$ Out of about 80 papers 30 are on Chinese astronomy and another 30 are on Indian astronomy, 10 are on Tibetan astronomy and the rest are on the history of astronomy in South-East Asia and Japan. About halves are written in English. A few papers are in Chinese. I can not grasp such a variety of areas, and what little I can evaluate is only those papers that deal with Indian astronomy.

Ôhashi's interest in Indian astronomy is divided in two fields: (1) history of mathematical astronomy from Vedic period to the Siddhāntic period. (2) history of astronomical instruments from Siddhāntic period to the Mughal period.

Concerning (1) Ôhashi made a significant contribution in the study of Jyotișa-Vedānga, criticizing David Pingree. ${ }^{2}$ Pingree thought that the number of civil days in the five year cycle (yuga) is 1825, in other words, a solar year consists of 365 days, and that this was borrowed from Egypt or Mesopotamia. But Ôhashi argued that a yuga consists of 1830 civil days and therefore a solar year is 366 days, which is purely of Indian origin. Ôhashi also rejected Pingree's idea of Mesopotamian origin of the ratio $2: 3$ of the shortest and longest day time found in the Jyotisa-Vedānga and other old Sanskrit texts. He showed that the ratio was derived not from the interpolation from the observation of the solstices but from the extrapolation from the observation around the equinoxes. As a result he concluded that the latitude of the Jyotisa-Vedāinga is about $27-29^{\circ}$ north. ${ }^{3}$

Ôhashi shared with me the interest in the Indian planetary theory. In the early 1990s we exchanged many letters discussing this topic. Especially I learned much from

\footnotetext{
1 "Bibliography of Dr. Yukio Ôhashi", with a short introductory note in Japanese, is to be published in the Journal of History of Mathematics, Japan, Tokyo.

${ }^{2}$ David Pingree, 'History of Mathematical Astronomy In India', Dictionary of Scientific Biography, Supplement, New York, 1978.

${ }^{3} \mathrm{His}$ first paper on this topics is IJHS 28(3), 1993 mentioned above. His recent paper is 'On Vedānga astronomy: The earliest systematic Indian astronomy', In Nakamura T., Orchiston W., Sôma, M. and Strom R. (eds.): Mapping the Oriental Sky, Proceedings of the Seventh International Conference on Oriental Astronomy, Tokyo, National Astronomical Observatory of Japan, 2011, pp. 164-170.
}

his letter dated January 8, 1990, where he showed how Neugebauer's explanation ${ }^{4}$ of 'halving the equation' in Indian astrnomy is not tenable and he drew a diagram of an example where Neugabauer's explanation did not work. His most important paper on the ancient planetary theory is 'Mathematical structure of the eccentric and epicyclic models in ancient Greece and India', contained in B.S. Yadav and S.L. Singh (eds.): History of the Mathematical Sciences II, Cambridge Scientific Publishers, 2011, pp. 83102, where he skillfully compared the Ptolemaic system and Indian models using figures neatly drawn by his hand. But he did not touch upon the difference of opinions between Neugebauer and van der Waerden [1961].

After I met Ôhashi in Mach last year, I wanted to study this problem again with him after the interval of about 30 years. Ôhashi was willing to work with me and he said that we can get some hints from van der Waerden's paper, especially about the possibility of the transmission of Greek 'equant' (Ausgleichspunkt) theory to India. It is a pity that we can not keep on exchanging ideas any more.

The second field where Ôhashi's achievements are remarkable is the history of astronomical instruments in India. The main part of his dissertation dealing with this topic was published in IJHS 29 (1994) and 32 (1997) as mentioned above. In IJHS 29 he analyzed Sanskrit texts dealing with astronomical instruments beginning with the Āryabhațiya of Āryabhața (born 476 CE) until Bhāskara II's Siddhāntaśiromaṇi (12th century). This article is the most informative one dealing with instruments. In IJHS 32 he offered detailed examinations of the astrolabe during the Delhi Sultanate. The astrolabe, which was called yantra-rāja (king of instruments), was one of the most popular astronomical instruments. In this paper Ôhashi first offered very useful explanation of the projection method in the astrolabe in general and then summarized the history of astrolabe beginning with the Yantrarāja (1370 CE) of Mahendra Sūri. The main part of this paper is on the Yantrarāja-adhikāra of Padmanābha (1423 CE). Ôhashi prepared for the first time a critical edition of the Sanskrit text using two manuscripts belonging to the University of Lucknow and he offered English translation and commentary of the whole text. This is really a monumental work in the history of astrolabe in India.

One of Ôhashi's important papers that deal with Tibetan astronomy is 'Remarks on the origin of Indo-

\footnotetext{
${ }^{4}$ See three items in References below.
} 
Tibetan astronomy', contained in Helaine Selin (ed.): $A s$ tronomy across Cultures, Kluwer Academic Publishers, 2000. After a brief summary of the history of Indian astronomy Ôhashi discusses 'Kālacakra astronomy' which belongs to the last stage of the history of the Esoteric Buddhist astronomy. The original Sanskrit text Kālacakratantra was translated into Tibetan and became the main source of the Tibetan astronomy. Ôhashi analyzed very carefully the Sanskrit text and its commentary $\mathrm{Vi}$ malaprabhā. He arrived at very important results: The epoch of the text was $1027 \mathrm{CE}$, the Jovian year prabhava according to the south Indian counting. But the same text gives a wrong number of the Hijra year. Ôhashi found that the mistake is due to the confused use of the Jovian year of the north Indian reckoning. In this way the text shows a strange nature of mixing south Indian and north Indian traditions. He further compared astronomical constants of classical Indian schools and showed that the Kālacakra's astronomical system is very close to that of the Ärdharātrika-pakșa (midnight school) that was initiated by Āryabhata. His argument is very convincing.

I am not qualified to judge Ôhashi's works on Chinese astronomy, but seeing his competence of mathematical analysis and Chinese language, I am sure that he has made an immense contribution to the scholarship of Chinese astronomy.

I deeply regret that I did not learn much from him while he was alive.

\section{References}

O. Neugebauer, 'The transmission of Planetary Theories in Ancient and Medieval Astronomy', Scripta Mathematica 22 (1956), pp. 165-192. Reprint in Neugebauer, Astronomy and History, SpringerVerlag, 1983, pp. 129-155.

O. Neugebauer, The Astronomical Tables of AlKhwārizmī, København, 1962.

O. Neugebauer and D. Pingree, The Pañcasiddhāntikā of Varāhamihira, København, Two Parts, 1970.

B. L. van der Waerden, 'Ausgleichspunkt, "Methode der Perser" und indische Planetenrechnung', Archive for History of Exact Sciences, Vol.1, Number 2, 1961, pp. 107-121.

\section{Appendix: A Select Bibliography of Yukio Ôhashi}

Here is a list of Yukio Ôhashi's publications in English. This is an extract from the full version prepared by Takao Hayashi mentioned in footnote 1 above.

\section{Abbreviations}

IJHS = Indian Journal of History of Science. [https : //insa.nic.in/UI/journal\protect । discretionary \{\char \hyphenchar \ font $\}\{\}\{\}$ details.aspx?AID=Mw==]

Selin 1997 = Encyclopaedia of the History of Science, Technology, and Medicine in Non-Western Cultures, ed. by Helaine Selin, Dordrecht/Boston/London, Kluwer, 1997.

Selin $2008=$ Encyclopaedia of the History of Science, Technology, and Medicine in Non-Western Cultures, ed. by Helaine Selin, Berlin: Springer, 2008.

\section{Papers in English}

1986a Sanskrit Texts on Astronomical Instruments during the Delhi Sultanate and Mughal Periods, Studies in History of Medicine and Science 10/11, New Delhi, 1986, 165-181. Actually published in 1991.

1987a A Note on Some Sanskrit Manuscripts on Astronomical Instruments, Proceedings of the International Astronomical Union, International Astronomical Union Colloquium, vol. 91: History of Oriental Astronomy, 1987, 191-195.

1988a Astronomical instruments of Bhāskara II and after, Scientific Heritage of India, ed. by B. V. Subbarayappa and S. R. N. Murthy, Bangalore: Mythic Society, 1988, 19-23.

1988b Varāhamihira's Orthographic Projection - An Interpretation of the Pañcasiddhāntikā XIV.5-11, Journal of the Asiatic Society 30(1-4), 1988, 66-76.

1990a A History of Astronomical Instruments in India(?), Lucknow: Lucknow Univeristy, 1990. 918pp. [Information from net but unidentified. Dissertation?] 
1993d Development of Astronomical Observation in Vedic and Post-Vedic India, IJHS 28(3), 1993, 185251.

1994a Astronomical Instruments in Classical Siddhāntas, IJHS 29(2), 1994, 155-313.

1994d History of Astronomical Instruments in India, Studies in History of Medicine and Science, New Series, 13(1), 1994, 113-114.

1995c Prof. K. S. Shukla's Contribution to the Study of the History of Hindu Astronomy, Ganita Bhāratī 17, 1995, 29-44.

1997a Early History of the Astrolabe in India, IJHS 32(3), 1997, 199-295.

1997e Astronomy in Tibet, Selin 1997, pp. 136-139.

1998e The Cylindrical Sundials in India, IJHS 33(4), 1998, Supplement, S147-S205.

1998f The Legends of Vasiṣtha - A Note on the Vedānga Astronomy, Highlights of Astronomy, Volume 11B: As Presented at the XXIIIrd General Assembly of the $I A U, 1997$, ed. by Johannes Andersen. Published online by Cambridge University Press, 2015, pp. 719721.

1999b Historical Significance of Mathematical Astronomy in Later-Han China, Current Perspectives in the History of Science in East Asia, ed. by Yung Sik Kim and Francesca Bray, Seoul: Seoul National University Press, 1999, pp. 259-263.

2000a Remarks on the Origin of Indo-Tibetan Astronomy, Astronomy across Cultures: A History of NonWestern Astronomy, ed. by H. Selin and X. Sun, Dordrecht: Kluwer, 2000, pp. 341-369.

2000d Early History of the Water-Driven Clock in the East - With Special Reference to India, Technology and History, Vol. 1, No. 1, Korean Society for the History of Technology and Industry, 2000, 37-67.

2001a A Preliminary Remarks on the Origin of "Mori" and "Mieri" in Chinese Calendars, Proceedings of the Fourth International Symposium on the History of Mathematics and Mathematical Education Using
Chinese Characters (18-21 August 1999, Maebashi), Maebashi: Maebashi Institute of Technology, 2001, 97-102.

2002a The Legends of Vasiștha - A Note on the Vedānga Astronomy, History of Oriental Astronomy, Proceedings of the Joint Discussion-17 at the 23rd General Assembly of the International Astronomical Union, organised by the Commission 41 (History of Astronomy), held in Kyoto, August 25-26, 1997, ed. by S. M. Ansari, Springer Netherlands, 2002, 75-82.

2002b Originality and Dependence of Traditional Astronomies in the East, Historical Perspectives on East Asian Science, Technology and Medicine, ed. by Alan K. L. Chan et al., Singapore: Singapore University Press and World Scientific, 2002, 394-405. Paper read at the Ninth International Conference on the History of Science in East Asia, 23-27 August 1999, Singapore.

2004d Medieval Indian Astronomical Instruments and Archives, Astronomical Instruments and Archives from the Asia-Pacific Region, ed. by W. Orchiston et al., Seoul: Yonsei University Press, 2004, pp. 125128.

2005c On the History of Mainland South-East Asian Astronomy, History of Science in the Multiculture: Proceedings of the Tenth International Conference on the History of Science in East Asia, ed. by Jiang Xiaoyuan, Shanghai: Shanghai Jiao Tong University Press, 2005, pp. 77-81 + 3 figures on pp. 85-86.

2006a The Riddle of the Cycle of Intercalation and the Sidereal Year: An Aspect of the Mainlad South-East Asian Calendars, Proceedings of the Fifth International Conference on Oriental Astronomy, ed. by K. Y. Chen, W. Orchiston, B. Soonthornthum, and R. Strom, Chiang Mai: Chiang Mai University, 2006, pp. 149-154.

2007b Formation of Chinese Classical Mathematical Astronomy, Gaṇita Bhāratī 29, 2007, 101-115.

2007c Interpolation of Yixing. Paper read at the 11th International Conference on History of Science and Technology in China, Nanning, 2007. Written in both English and Chinese. 
2008a Astronomy: Indian Astronomy in China, Selin 2008, pp. 321-324.

2008b Astronomy in mainland Southeast Asia, Selin 2008, pp. 354-360.

2008c Astronomy in Tibet, Selin 2008, pp. 375-379.

2008d Chinese Mathematical Astronomy from ca. 4th Century to ca. 6th Century, Gaṇita Bhāratī 30(1), 2008, 27-39.

2008e Introduction of Persian Astronomy into India, Tārīkh-e 'Elm (Iranian Journal for the History of Science) 6, 2008, 49-74.

2008f Obituary: Kripa Shankar Shukla (1918-2007), IJHS 43(3), 2008, 475-485.

2009a The Mathematical and Observational Astronomy in Traditional India, Science in India, (part 8 of vol. 13 in History of Science, Philosophy and Culture in Indian Civilization ed. by D. P. Chattopadhyaya), ed. by J. V. Narlikar, New Delhi: Viva Books, 2009, pp. $1-88$.

2011b Astronomy and Mathematics of Yixing, Mapping the Oriental Sky, ed. by Tsuko Nakamura, Wayne Orchiston, Mitsuru Sôma, and Richard Strom, Tokyo: National Astronomical Observatory of Japan, 2011, pp. 171-178.

2011c Mathematical Structure of the Eccentric and Epicyclic Models in Ancient Greece and India, History of the Mathematical Sciences II, ed. by B. S. Yadav and S. L. Singh, Cambridge: Cambridge Scientific Publishers, 2011, pp. 83-102.

2015a Astronomy of the Vedic Age, Handbook of Archaeoastronomy and Ethnoastronomy, ed. by Clive L. N. Ruggles, New York: Springer New York, 2015, pp. 1949-1958.

2017a Indianized Astronomy in Asia. The History of World Calendars and Calendar-making: Proceedings of the International Conference in Commemoration of the 600th Anniversary of the Birth of Kim Dam, ed. by I.-S. Nha, W. Orchiston, and F. R. Stephenson, Seoul, 2017, pp. 145-152. 2018a Astronomy of Taiwanese Austronesian People, Proceedings of the Sixth Symposium on History of Astronomy, ed. by Mitsuru Sôma and Kiyotaka Tanikawa, National Astronomical Observatory of Japan, 2017, pp. 54-65.

2018b Southeast Asian Traditional Astronomy at the Crossroad: Local Original Astronomy and the Influence of China, India, the Islamic World and the West. 'Nearly final draft' dated 20180912. [Published?] 